\title{
DAMPAK BENCANA GEMPA BUMI TERHADAP KONDISI SOSIAL EKONOMI MASYARAKAT DI KABUPATEN LOMBOK UTARA
}

\author{
Andrianus Andi ${ }^{1)}$ \\ Laili Hurriati $^{2)}$ \\ Universitas Islam Al-Azhar 1) \& 2) \\ ${ }^{1)}$ Email: Andrianandi22@gmail.com \\ ${ }^{2)}$ Email: lailihurriati.86@gmail.com
}

\begin{abstract}
This study entitled "The Impact of Earthquakes on the Socio-Economic Condition of Communities on Lombok Nort ". In this study the researchers tried to try to study the phenomenon of the impact of the Lombok earthquake on the socio-economic conditions of the affected communities, especially North Lombok Regency.

The type of this research is qualitative research with a documentation study approach, namely research conducted by looking at the documents that are then interpreted. Based on the results of the study, it can be explained about the socio-economic impact of the earthquake in Lombok in the affected communities, namely North Lombok District. from the socio-economic conditions of the community, which were many losses and damage that were affected by the people of North Lombok, both morally and materially, the Lombok earthquake had a significant impact on the conditions of Demography, health, education and the condition of the local housing area, especially in North Lombok Support. Nearly half of the population in North Lombok Regency who were displaced and several other people died, this has caused a large influence from the earthquake on the composition of the community's demography in North Lombok Regency. On the economic side, many people who lost their livelihoods, based on the results of the Lombok earthquake, especially for traders, who were originally able to earn 1-1.5 million per day but after the earthquake Lombok decreases their income by 50\%. besides that, this earthquake caused a decrease in local revenue (PAD) in North Lombok Regency.
\end{abstract}

\section{Keywords: The Earthquake Economic Impact of the Lombok Earthquake}

\section{PENDAHULUAN}

Indonesia merupakan negara yang dilalui oleh 3 lempeng tektonik, yaitu lempeng Indo-Australia, lempeng Eurasia, lempeng Pasifik. Lempeng tersebut bergerak sangat lambat dan manusia tidak dapat merasakannya, namun tercatat 0-15 cm pergerakannya dalam setahun ${ }^{1}$.

Pulau Lombok merupakan salah satu pulau di Indonesia yang rawan akan gempa bumi. Berdasarkan hasil pencatatan United State Geological Survey (USGS), Pulau Lombok terutama di Kota Mataram kerap kali mengalami gempa

\footnotetext{
${ }^{1}$ Wikepedia// Earth. Diakses tanggal 15 september 2018.
} 
bumi dengan kekuatan gempa cukup besar dan hiposenter yang dangkal. Menurut pencatatan Badan Meteorologi Klimatologi dan Geofisika (BMKG), sejak 40 tahun terakhir telah terjadi lebih dari 2000 kali kejadian gempa bumi yang pernah terjadi di Pulau Lombok, bahkan gempa bumi merusak juga telah terjadi beberapa kali di Pusat Kota . Seperti gempa dengan kekuatan 5,4 Skala Ritcher berpusat $14 \mathrm{~km}$ barat laut Lombok Barat dengan kedalaman hiposenter $10 \mathrm{~km}$ telah mengguncang berbagai daerah di Pulau Lombok dan sekitarnya pada tanggal 22 Juni 2013. Dan gempa bumi yang terbaru yaitu gempa dengan magnitude berkekuatan 7.0 Skala Ritcher yang terjadi pada pukul 21.56 WIB tanggal 19 Agustus 2018. Gempa tersebut berada pada kedalaman 10 kilometer. Berdasarkan Catatan dari Badan Penanggulangan Bencana Daerah (BPBD) memperlihatkan kerusakan fasilitas umum dan pemukiman mencapai ribuan. Selain itu jumlah korban yang meninggal dunia juga mencapai 500 orang lebih dan korban luka-luka mencapai 7000 lebih, (BPBD. Provinsi Nusa Tenggara Barat 2018) . Fakta ini jika disandingkan dengan sifat gempa bumi yang berulang untuk periode waktu tertentu (earthquake cycle) menunjukkan potensi ancaman gempa bumi di pulau lombok pada masa yang akan datang masih sangat tinggi.

Selain korban jiwa, gempa bumi yang terjadi di pulau Lombok juga menimbulkan kerugian secara ekonomi. Berdasarkan data dari Pusat Data Informasi dan Humas Badan Nasional Penanggulangan Bencana (BNPB) kerugian ekonomi yang diakibatkan oleh gempa Lombok mencapai 7.4 triliun lebih. Menurut kepala BNPB kerugian tersebut meliputi kerugian akibat kerusakan sektor pemukiman, sektor infrastruktur dan sektor ekonomi produktif. Begitu besarnya kerugian ekonomi yang diakibatkan oleh bencana ini menyebabkan pemerintah daerah NTB dan pusat kehilangan sumber dana dan telah memberikan tekanan yang sangat kuat terhadap anggaran belanja pemerintah.

Akibat gempa bumi yang melanda pulau Lombok, pemerintah pusat harus mengeluarkan dana 4 triliun lebih untuk menanggulangi dampak yang diakibatkan oleh gempa bumi tersebut. Dana tersebut diberikan untuk pembangunan kembali infrastruktur publik dan perumahan warga yang rusak akibat gempa. Kepala Bapenas Bambang Brodjonegoro mengatakan bahwa gempa yang terjadi di pulau Lombok akan berdampak pada memburuknya kondisi perekonomian di daerah yang ada di 
Pulau Lombok pada khususnya dan NTB pada umumnya. Proses pemulihan ekonomi di pulau Lombok atau provinsi NTB secara umum akan memerlukan waktu 6-12 bulan. Perlambatan pertumbuhan ekonomi yang terjadi akibat gempa di pulau Lombok akan menyebabkan naiknya tingkat inflasi, tingkat kemiskinan, dan pengangguran.

Meskipun upaya penanggulangan bencana telah dilakukan oleh pemerintah daerah dan pemerintah pusat melalui instansi-instansi terkait dan oleh lembaga atau organisasi non pemerintah, namun bencana gempa tetap menunjukkan adanya kerugian ekonomi yang sangat besar dalam bentuk penurunan aset-aset produksi di sektor-sektor terkait, dan juga penurunan kesejahteraan rakyat secara tidak langsung. Penurunan aset-aset produksi di sektor tertentu akan berdampak pada sektor-sektor lainnya dalam bentuk keterkaitan input dan outputnya. Selain itu juga berdampak pada penyerapan faktor produksi dan pendapatan instansi-instansi terkait. Hal ini tentunya akan berdampak pada terhambatnya pertumbuhan ekonomi pulau Lombok atau provinsi NTB secara umumnya.

Berdasarkan latar belakang yang telah diuraikan di atas, maka perlu adanya penelitian yang berkaitan tentang analisis dampak gempa bumi terhadap sosial ekonomi.

\section{KAJIAN PUSTAKA}

\section{Gempa Bumi}

Undang-undang nomor 2, bencana adalah peristiwa atau rangkaian peristiwa yang mengancam dan mengganggu kehidupan dan penghidupan masyarakat yang disebabkan, baik oleh faktor alam dan/atau faktor nonalam maupun faktor manusia sehingga mengakibatkan timbulnya korban jiwa manusia, kerusakan lingkungan, kerugian harta benda, dan dampak psikologis.

Secara umum gempa bumi disebabkan dari pelepasan energi yang dihasilkan oleh tekanan yang disebabkan oleh lempengan yang bergerak. Semakin lama tekanan itu kian membesar dan akhirnya mencapai pada keadaan dimana tekanan tersebut tidak dapat ditahan lagi oleh pinggiran lempengan. Sedangkan menurut Ohnaka gempa bumi disebabkan karena adanya energy yang tersimpan akibat terjadinya gerakan relative antara lempeng yang mengakibatkan meningkatnya tekanan, sehingga energy renggangan tersimpan pada sekitar permukaan patahan, ini terus 
Jurnal Kompetitif : Media Informasi Ekonomi Pembangunan, Manajemen dan Akuntansi Vol. 6 No. 2, September 2020

berlanjut sampai tekanan meningkat cukup untuk menerobos asperity, kemudian secara tiba-tiba memungkinkan meluncur di atas bagian yang terkunci dari patahan, dan melepaskan energi yang tersimpan sehingga terjadinya gempa bumi. ${ }^{2}$

\section{Dampak Bencana}

Dampak bencana dalam tataran sistem sosial-ekonomi yang beragam diakibatkan dari kelangkaan informasi dan metodologi yang belum bisa bersifat universal dalam mengukur dampak bencana. European Commission for Latin America and Caribbean (ECLAC) mengusulkan sebuah metodologi yang dirancang untuk melakukan penilaian dampak bencana bagi ekonomi ${ }^{3}$, yang dibedakan dalam tiga kelompok: Pertama, Direct damages (kerusakan langsung), meliputi semua kerusakan pada aset tetap, modal dan persediaan barang jadi dan setengah jadi, bahan baku dan suku cadang yang terjadi secara bersamaan sebagai konsekuensi langsung. Pada tahap ini akan menyangkut pengeluaran untuk bantuan darurat. Kedua, Indirect damages (kerusakan tidak langsung), dampaknya lebih pada arus barang yang tidak akan diproduksi dan jasa yang tidak akan diberikan setelah bencana. Kerusakan tidak langsung ini dapat meningkatkan pengeluaran operasional karena rusaknya infrastruktur. Biaya yang bertambah terletak pada penyediaan layanan alternatif (alternatif cara produksi, distribusi dan penyediaan barang dan jasa). Ketiga, Secondary effect (dampak sekunder), meliputi dampak pada kinerja ekonomi secara keseluruhan yang diukur melalui variabel ekonomi makro yang paling signifikan. Variabel yang paling relevan terdapat Produk pada Domestik Bruto (PDB) yang mencakup keseluruhan dan sektoral, neraca perdagangan dan neraca pembayaran, tingkat utang dan cadangan moneter, keadaan keuangan publik dan investasi modal bruto. Pada sisi keuangan publik seperti penurunan pendapatan pajak atau peningkatan pengeluaran dapat menjadi sangat penting. Dampak sekunder ini akan sangat dirasakan pada tahun fiskal dimana bencana terjadi, namun memungkinkan juga berdampak pada tahun fiskal selanjutnya.

\footnotetext{
${ }^{2}$ Ohnaka, (2013), The Physics of Rock Failure and Earthquakes. Buku Seismologi, BMKG., Jakarta.

${ }^{3}$ Zapata-Marti, R.,(1997), Methodological approaches: the ECLAC methodology. In Center for the Research on the Epidemiology of Disasters (CRED), Assessment of the economic impact of natural and man-made disasters. Proceedings of the expert consultation on methodologies, Brussels, 29-30 September, Universite Catholique de Louvain, Belgium, 10-12.
} 
AusAID membagi dampak ekonomi makro dari bencana alam dalam dua kelompok, yaitu dampak nyata dan dampak tidak nyata. Kedua kelompok tersebut akan mempengaruhi perubahan variabel-variabel ekonomi makro. Berikut variable variable ekonomi makro yang dipengaruhi bencana: (1) Produk Domestik Bruto (PDB), PDB dan pertumbuhan PDB dapat turun karena turunnya produksi dan pendapatn sektor-sektor yang terkena dampak bencana. Namun bencana juga dapat memiliki dampak positif pada PDB jika ada peningkatan ekonomi untuk rekonstruksi. Proyeksi membutuhkan estimasi tentang bagaimana sektor-sektor dalam PDB beraktivitas tanpa bencana. Jika angka PDB sektoral tersedia, dapat juga digunakan untuk menilai dampak bencana terhadap pertumbuhan sektor yang berbeda. Pengukuran yang dilakukan pada tingkat riil pada harga konstan. (2) Investasi Bruto, Bencana menimbulkan pengaruh negatif bagi investasi bruto, yaitu menyebabkan turunnya harga saham, dan pembatalan proyek-proyek pembangunan yang sedang berlangsung. Bencana juga dapat meningkatkan investasi bruto sebagai restorasi terhadap aset dan dimulainya upaya rekonstruksi. Sehingga diperlukan estimasi baik dampak negatif dan positif bencana pada investasi bruto. (3) Keuangan Publik, Keseimbangan pengeluaran sektor publik kemungkinan berubah pasca bencana, dan biasanya akan memperluas defisit fiskal. Pengeluaran sektor publik pada umumnya meningkat setelah bencana sebagai akibat dari pengeluaran untuk tahap darurat, pemulihan, rehabilitasi dan rekonstruksi. Pendapatan fiskal biasanya akan jatuh setelah bencana karena penurunan penerimaan pajak. Sebagian gangguan pada anggaran pemerintah terjadi karena adanya distribusi untuk memenuhi biaya rehabilitasi yang memaksa pemerintah untuk memotong angaran program pembangunan, menangguhkan sampai mengakhiri proyek-proyek penting. (4) Inflasi barang yang diproduksi dan kerusakan sarana transportasi. Harga juga mungkin meningkat jika ada permintaan baru untuk barang dan layanan untuk rekonstruksi. Sehingga idealnya pengaruh bencana terhadap perubahan harga secara relatif maupun umum harus diperhatikan. (5) Pekerjaan, Bencana dapat menyebabkan perubahan pada struktur lapangan kerja, karena kerusakan dan kehancuran kapasitas produksi, infrastruktur sosial dan perubahan kondisi selama proses rekonstruksi dan 
Jurnal Kompetitif : Media Informasi Ekonomi Pembangunan, Manajemen dan Akuntansi Vol. 6 No. 2, September 2020

rehabilitasi. Jika memungkinkan tidak hanya perubahan dalam pekerjaan, tetapi juga dampak yang dihasilkan pada pendapatan masyarakat. ${ }^{4}$

\section{Kondisi Sosial Ekonomi Penduduk}

\section{Kondisi Sosial}

Kata sosial dalam buku Sosiologi Suatu Pengantar Soerjono Soekanto, berarti berkenaan dengan masyarakat (dalam penelitian ini adalah penduduk). Kondisi sosial penduduk dikaji melalui empat variabel yaitu kondisi demografis, kesehatan, pendidikan, dan kondisi perumahan. ${ }^{5}$

a. Kondisi Demografis, Demografi merupakan istilah yang berasal dari dua kata Yunani, yaitu demos yang berarti rakyat atau penduduk dan grafien yang berarti tulisan $^{6}$. United Nations dalam Sri Moertiningsih mendefinisikan demografi sebagai studi ilmiah masalah penduduk yang berkaitan dengan jumlah, struktur, serta pertumbuhannya.

b. Kesehatan, Sehat berarti suatu keadaan sempurna baik jasmani, rohani, maupun kesejahteraan sosial seseorang (kesimpulan penulis). Menurut Undang-Undang Republik Indonesia No. 23 Tahun 1992 tentang Kesehatan, menyatakan bahwa kesehatan adalah keadaan sejahtera dari badan, jiwa dan sosial yang memungkinkan seseorang hidup produktif secara sosial dan ekonomi.

c. Pendidikan, Menurut Undang-Undang Republik Indonesia No. 20 Tahun 2003 tentang Sistem Pendidikan Nasional, pendidikan adalah usaha sadar dan terencana untuk mewujudkan suasana belajar dan proses pembelajaran agar peserta didik secara aktif mengembangkan potensi dirinya untuk memiliki kekuatan spiritual keagamaan, pengendalian diri, kepribadian, kecerdasan, akhlak mulia, serta keterampilan yang diperlukan dirinya, masyarakat, bangsa dan negara.

d. Kondisi Perumahan, Perumahan merupakan kebutuhan pokok di samping sandang dan pangan. Rumah yang baik adalah rumah yang memenuhi persyaratan kesehatan ${ }^{7}$. Secara umum, rumah yang sehat dan nyaman ialah bangunan tempat kediaman suatu keluarga yang lengkap, berdiri sendiri, cukup

\footnotetext{
${ }^{4}$ AusAID, (May 2005), Economic Impact of Natural Disasters on Development in The Pacific

5 Soekanto, Soerjono. (1982). Sosiologi Hukum dalam. Masyarakat,Jakarta : CV. Rajawali. Afrizal. 2014.

${ }^{6}$ Sri Moertiningsih. (2011). Dasar-Dasar. Demografi Edisi Revisi 2. Jakarta: Selamba Empat.

${ }^{7}$ Gilarso. (1994) . Pengantar Ilmu Ekonomi Makro. Edisi Pertama. IKAPI. Yogyakarta.
} 
awet, dan cukup kuat rekontruksinya. Kondisi perumahan penduduk dalam penelitian ini adalah suatu kriteria yang akan menunjukkan tingkat kerusakan rumah dengan cara menilai unsur-unsur fisik rumah. Unsur-unsur tersebut meliputi keadaan atap, dinding, dan lantai. Tingkat kerusakan rumah dibagi menjadi tiga, yaitu rusak berat (atap rusak, dinding jebol, lantai terkikis/hanyut), rusak sedang (dinding terkikis dan sebagian atap hilang), dan rusak ringan (jendela dan pintu jebol).

\section{Kondisi Ekonomi Penduduk}

Kondisi ekonomi penduduk adalah keadaan yang menggambarkan kehidupan manusia yang mempunyai nilai ekonomi. Kondisi ekonomi dikaji melalui tiga variabel yaitu mata pencaharian, pendapatan, dan kepemilikan barang berharga.

a. Mata Pencaharian, Mata pencaharian adalah aktivitas melakukan pekerjaan dengan tujuan memperoleh penghasilan atau keuntungann untuk memenuhi kebutuhan hidupnya yang dilakukan secara berturut-turut dan tidak terputus termasuk pekerja keluarga tanpa diberi upah yang membantu dalam kegiatan ekonomi dan dapat memenuhi kesejahteraan hidupnya (kesimpulan penulis)

b. Pendapatan, Menurut Soediyo, pendapatan adalah jumlah penghasilan yang diterima oleh anggota masyarakat pada jangka waktu tertentu sebagai balas jasa atas faktor-faktor produksi yang mereka sumbangkan ${ }^{8}$, sedangkan Mulyanto menyatakan pendapatan merupakan seluruh penerimaan baik yang berupa uang maupun barang, baik dari pihak lain atau dari hasil sendiri dinilai dengan uang atas dasar harga pada saat itu.

\section{Penelitian Terdahulu}

Penelitian yang dilakukan oleh Novenanto (2017), melihat Kasus Lapindo Sebagai Bencana Sosial. Artikel ini membahas kasus Lapindo tidak hanya sebagai bencana fisik, tetapi sebagai bencana sosial. Insiden yang terjadi telah mengancam orang-orang dari Porong Sidoarjo dan juga memukul ekonomi Jawa Timur dan berpengaruh terhadap program pembangunan Indonesia. Tidak ada banyak artikel di perspektif ilmu sosial tentang kejadian ini. Artikel ini dibangun berdasarkan penulis penelitian lapangan di Porong Sidoarjo untuk mengeksplorasi, baik tinggi dan

8 Soediyono. (1992). Ekonomi Makro Pengantar Analisa Pendapatan. Jurnal JEB Volume 3 no 2 Oktober 2018 
Jurnal Kompetitif : Media Informasi Ekonomi Pembangunan, Manajemen dan Akuntansi Vol. 6 No. 2, September 2020

rendah, aspek politik ekonomi dari kasus Lapindo. Penulis menemukan bahwa hancurnya ruang publik karena semburan lumpur yang telah menyebabkan kerugian dalam bentuk segi sosial yang menyebabkan bencana sosial politik yang serius. ${ }^{9}$

Penelitian Ramanditya (2014) tentang "Integrasi Rehabilitasi Sosio Ekonomi Penduduk Setelah Gunung Merapi Tahun 2010 terhadap Perencanaan Pemulihan”. bencana erupsi Gunung Merapi tahun 2010 tidak hanya memberikan dampak fisik kepada masyarakat lokal, tetapi masyarakat harus menghadapi dampak sosial dan ekonomi yang datang pasca bencana. Untuk mengurangi dampak negatif dan mendorong kehidupan yang berkelanjutan, diperlukan perencanaan pemulihan yang mengatur strategi pemulihan. Namun, berdasarkan penelitian sebelumnya, terdapat peran yang dominan masyarakat lokal dalam menginisiasi aktivitas pemulihan. Artikel ini bertujuan untuk mengetahui sejauh mana kebijakan perencanaan pemulihan pasca bencana Gunung Merapi tersebut sudah memfasilitasi upaya pemulihan sosial-ekonomi masyarakat yang efektif, efisien dan berkelanjutan dan mengurangi kerentanan sosial-ekonomi yang ada. ${ }^{10}$

Penelitian Anastasia (2010) tentang "Perubahan Pekerjaan Masyarakat Sebagai Akibat dari Bencana (Studi kasus Kawasan Wisata Vulcano Tour Gunung Merapi, Desa Umbulharjo, Cangkringan, Sleman)". Bencana Gunung Merapi pada tahun 2010 menyebabkan berbagai dampak dalam tatanan kehidupan masyarakat. Aset penghidupan masyarakat hancur dan produksi ekonomi pun menurun. Hal ini mengindikasikan bahwa masyarakat yang tinggal di daerah bencana mengalami kehilangan pekerjaan. Di sisi lain, kerusakan wilayah akibat bencana justru menjadi daya tarik wisata yang dapat memunculkan peluang kerja baru sehingga dibuka lah Kawasan Wisata Volcano Tour. Penelitian ini bertujuan untuk menganalisis dampak bencana gunung api terhadap perubahan pekerjaan masyarakat di wilayah studi. Metode yang digunakan adalah analisis kualitatif semi-etnografi dengan teknik pengambilan sampel purposive sampling. Dari penelitian ini dapat disimpulkan bahwa bencana berdampak pada perubahan pekerjaan masyarakat karena masyarakat yang kehilangan pekerjaan mampu memanfaatkan peluang kerja di tempat lain

9 Novenanto Anton. 2017. "Melihat Kasus Lapindo Sebagai Bencana Sosial”. Journal Unair. www.journalUnair.ac.id (diakses pada tanggal 18 oktober 2018)

${ }^{10}$ Ramanditya.2014."Integrasi Rehabilitasi Sosio Ekonomi Penduduk Setelah Gunung Merapi Tahun 2010 terhadap Perencanaan Pemulihan. www.rdi.or.id (diakses pada tanggal 18 otoberr 2018) 
Jurnal Kompetitif : Media Informasi Ekonomi Pembangunan, Manajemen dan Akuntansi Vol. 6 No. 2, September 2020

sebagai sumber penghidupan baru. Ada pun hal utama yang direkomendasikan adalah keberadaan dukungan pemerintah untuk menciptakan pekerjaan berkelanjutan bagi masyarakat. ${ }^{11}$

\section{METODE PENELITIAN}

Metode penelitian yang dilakukan dalam penelitian ini adalah metode penelitian kualitatif. Penelitian kualitatif dilakukan dengan melihat dokumendokumen yang tersedia dan melakukan wawancara dengan berbagai narasumber dan sifat penelitian kualitatif dari penelitian ini adalah Dokumen Study. ${ }^{12}$

\section{PEMBAHASAN}

\section{Kondisi Kabupaten Lombok Utara Sebelum Gempa}

\section{Kondisi Sosial}

Terkait dengan kondisi sosial ini ada beberapa indikator untuk mengukur kondisi sosial ini dalam penelitian ini. Dalam penelitian ini indikator untuk mengukur bahwa bagaimana perubahan kondisi sosial masyarakat sebelum gempa dan pasca gempa adalah, demografi, kesehatan, pendidikan dan kondisi perumahan. Terkait dengan hal tersebut adalah sebagai berikut :

Kondisi Demografi, Terkait dengan kondisi demografi atau kependudukan Kabupaten Lombok Utara ini pada tahun 2017 tercatat berdasarkan data dari BPS Kabupaten Lombok Utara bahwa penduduk Kabupaten Lombok Utara berjumlah 216. 515 orang, yang tersebar diberbagai lokasi. Kabupaten Lombok Utara terdiri dari 5 kecamatan dengan berbagai jumlah penduduk.

Kondisi Kesehatan, Terkait dengan penelitian ini bahwa indikator untuk mengukur kesehatan ini adalah banyaknya fasilitas kesehatan yang tersedia di wilayah tersebut. Terkait dengan fasilitas kesehtan ini maka alat ukurnya adalah jumlah rumah sakit, puskesmas serta postu dan polindes. Berdasrkan data tahun 2017 mengenai fasilitas kesehatan di Kabupaten Lombok Utara secara keseluruhan jumlah fasilitas kesehatan yang ada di Kabupaten Lombok Utara sebanyak 56 unit pada tahun 2017.

Kondisi Pendidikan, Terkait kondisi pendidikan bahwa dalam penelitian ini pendidikan yang dijadikan sebagai indikator dalam penelitian ini adalah jumlah

\footnotetext{
11 Anastasia. 2010."Perubahan Pekerjaan Masyarakat Sebagai Akibat dari Bencana (Studi kasus Kawasan Wisata Vulcano Tour Gunung Merapi, Desa Umbulharjo, Cangkringan, Sleman). elib.unikom.ac.id (diakses pada tanggal 18 oktober 2018

12 J.Moleong, Steven.1999 .Metodologi Penelitian Kualitatif. Bandung: Remaja Rosdakarya
} 
fasilitas pendidikan, baik itu milik pemerintah maupun milik swasta. Terkait dengan jumlah fasilitas pendidikan di Kabupaten Lombok Utara sebanyak 290 unit, dan terdiri dari 151 unit untuk SD, 35 unit untuk MI, 35 unit Untuk SMP, 44 unit untuk MTS, 13 unit untuk SMA dan 12 Unit untuk SMK.

Kondisi Perumahan, Dalam kaitannya dengan penelitian ini, salah satu indikator sosial yang digunakan dalam penelitian ini adalah kondisi perumahan. Terkait dengan kondisi perumahan yang ada di Kabupaten Lombok Utara berikut merupakan gambaran kondisi perumahan di Kabupaten Lombok Utara perkecamatan pada tahun 2017. Adapun jumlah bangunan rumah tempat tinggal di Kabupaten Lombok Utara perkecamatan, paling banyak berada di Kecamatan Bayan yaitu sebanyak 12.191 rumah, sedangkan yang paling sedikit berada di Kecamatan Gangga yaitu sebanyak 10.076 rumah.

\section{Kondisi Ekonomi}

Kaitannya dengan kondisi ekonomi, dalam penelitian ini instrumen untuk mengukur kondisi ekonomi dalam penelitian ini adalah, mata pencaharian dan pendapatan.

Kondisi Mata Pencaharian, Dilihat dari struktur perekonomian, sektor keuangan, jasa, bangunan dan pengangkutan merupakan sektor perekonomian yang merupakan tulang punggung perekonomian Kabupaten Lombok Utara dalam lima tahun terakhir ini. Bersama dengan sektor industri pengolahan, sektor-sektor ini terus berusaha meningkatkan intensitas kegiatan pembangunan Kabupaten Lombok Utara di segala bidang.

Kondisi Pendapatan, Terkait dengan pendapatan ini, maka konsep yang diterapkan dalam penelitian ini adalah bagaimana mengenai PAD di Kabupaten Lombok Utara. Anggaran Pendapatan dan Belanja Daerah (APBD) merupakan rencana pengelolaan keuangan tahunan pemerintah daerah yang disetujui oleh DPRD dalam Peraturan Daerah (Perda). APBD merupakan komitmen penyelenggara pemerintahan daerah untuk mendanai strategi pembangunan pada satuan program dan kegiatan selama kurun waktu 1 tahun.

Sampai sejauh ini, sumber pendapatan daerah Kabupaten Lombok Utara sebagian besar tergantung pada Dana Alokasi umum (DAU), sedangkan persentasi Pendapatan Asli Daerah (PAD) Kabupaten Lombok Utara terhadap APBD 
Kabupaten Lombok Utara berkisar 4,79 \% dari total APBD murni untuk Tahun 2011, sehingga upaya peningkatan sumber PAD perlu dilakukan tanpa menimbulkan biaya ekonomi biaya tinggi sehingga tidak memberatkan masyarakat.

Peranan Dana Alokasi Umum (DAU) dan Dana Bagi Hasil dalam pembiayaan pembangunan di Kabupaten Lombok Utara. Dalam upaya mewujudkan Kabupaten Lombok Utara sebagai pusat pariwisata, pendidikan dan perekonomian yang berkelanjutan, perlu dilakukan pembenahan ekonomi, sosial, dan lingkungan yang seimbang. Untuk itu, ruang gerak anggaran perlu lebih dioptimalkan tidak hanya melalui mobilisasi sumber pendapatan, tetapi juga perlu dilakukan proses penganggaran partisipatif (participatory budgeting) dengan melibatkan seluruh stakeholders. Dalam upaya memenuhi kebutuhan pembangunan infrastruktur kota, perlu dikembangkan pula model pembiayaan public-private partnership. Pembiayaan jenis terakhir ini memerlukan kerjasama antara pemerintah dan swasta dalam pembiayaan pembangunan. Diharapkan kerjasama antara swasta dan pemerintah ini mampu mempercepat laju pembangunan di Kabupaten Lombok Utara.

\section{Kondisi Kabupaten Lombok Utara Pasca Gempa Bumi}

Pada hari Minggu, 29 Juli 2018 pukul 06.47 WITA telah terjadi gempa bumi dengan kekuatan 6.4 SR di titik koordinat 8.26 LS 116.55 BT atau $28 \mathrm{~km}$ sebelah Timur Laut Lombok Timur, Provinsi Nusa Tenggara Barat. Gempa tidak berpotensi tsunami. Kemudian pada hari Minggu, 05 Agustus 2018 pukul 20.46 WITA telah terjadi gempabumi yang ditetapkan sebagai Main Shock gempa dengan kekuatan 7 SR di Lombok Utara, Provinsi Nusa Tenggara Barat. Pascagempabumi terjadi tsunami kecil di Carik setinggi 0,135 meter dan di Badas setinggi 0,100 meter. Pada tanggal 19 Agustus 2018 pukul 22.56 WITA, BMKG mencatat telah terjadi gempa dari sistem patahan baru dengan kekuatan 6.9 SR dan lebih dari 5 kali gempa susulan dengan magnitudo>5.0 SR. (BNPB Prov. NTB 2019)

\section{Kondisi Sosial Masyrakat Pasca Gempa}

Terkait dengan kondisi sosial ini, dalam penelitian ini adapun konsep yang digunakan sebagai komparasi dalam melihat dampak gempa ini adalah, kondisi demografi, kondisi kesehatan, pendidikan dan kondisi perumahan. Terkait dengan hal tersebut, berikut dampak gempa terhadap sosial yang ada di lokasi penelitian . 
Kondisi Demografi, Terkait hasil wawancara dengan Kepala humas BPBD Provinsi Nusa tenggara Barat, bahwa gempa Lombok ini sangat memberikat dampak yang begitu signifikan terhadap kondisi demografi khususnya di Kabupaten Lombok Utara, dengan keadaan ini banyak penduduk Kabupaten Lombok Utara yang mengungsi sehingga hal ini akan mengurangi jumlah penduduk dan komposisi demografi yang ada di Kabupaten Lombok Utara. Selain itu juga penduduk Kabupaten Lombok Utara selalu di selimuti oleh ketakutan akan gempa susulan yang terus terjadi sampai sekarang, meskipun intensitasnya tidak seperti pada tahun 2018 kemarin, dan juga akibat gempa ini banyak penduduk yang masih mengalami trauma, tetapi ada juga penduduk yang sudah pulih dan mulai beraktifitas seperti sedia kala.

Kondisi Kesehatan, Terkait dengan kondisi kesehatan ini adapaun instrumen untuk mengukur dampak gemapa Lombok ini terhadap kondisi kesehatan masyrakat adalah jumlah fasilitas kesehtan yang rusak, yakni seperti rumah sakit, puskesmas, postu, dan sebagainya, artinya yang berkaitan dengan unsur fisik fasilitas kesehatan. Berdasrkan keterangan dari salah satu bagian Humas BPBD Provinsi NTB, bahwa dampak gempa tersebut banyak membuat kerusakan khusunya untuk bangunan fasilitas kesehatan di Kabupaten Lombok Utara, hal ini menjadi suatu permasalahn bagi pemerintah daerah maupun pusat. Selain itu juga kerusakan dari fasiltas kesehatn ini membuat banyak tenda-tenda darurat yang dibangun untuk pelayanan kesehatan sementara, meskipun pe;layanan tidak begitu maksimal bagi para pasien, tetapi hal ini harus diadakan. Untuk itu gempa di Lombok ini memberikan dampak yang sangat signifikan terhadap kondisi kesehatan masyrakat yang ada di Kabupaten Lombok Utara hal ini dikarenakan akses untuk pelayanan kesehatan banyak yang rusak sehingga menyebabkan turunnya tingkat kesehatan di Masyarakat Kabupaten Lombok Utara.

Kondisi Pendidikan, Dari keterangan bagian Humas BPBD Provinsi NTB gempa Lombok memberikan dampak yang sangat signifikan bagi pendidikan di Kabupaten Lombok Utara, hal ini memberikan dampak menurunnya tingkat kualitas pelayanan pendidikan di Kabupaten Lombok Utara dikarenakan banyaknya fasilitas pendidikan seperti sekolah yang mengalami kerusakan, hal ini menjadi tanggung jawab pemerintah daerah dan pusat bagaimana memberikan tindak lanjut untuk 
memperbaiki kulaitas pendidikan atau fasilitas pendidikan seperti sekolah, karena pendidikan merupakan investasi penting untuk membangun suatu daerah bahkan suatu negara.

Kondisi Perumahan, Berdasarkan hasil wawancara dengan Bagian Humas BPBD Provinsi NTB, bahwa gempa Lombok ini sangat berdampak signifikan terhadap kondisi perumahan masyrakat Kabupaten Lombok Utara. Banyak rumah yang rusak atau bahkan hampir seluruh rumah di Kabupaten Lombok Utara terindentifikasi rusak, hal ini membuat banyak dari para warga masyrakat yang tinggal di poskoposko pengungsian dan tenda-tenda darurat yang dibangun sendiri oleh warga, hal ini dikarenakan akibat kerusakan rumah dari para warga masyrakat Kabupaten Lombok Utara.

\section{Kondisi Ekonomi Masyrakat Pasca Gempa}

Kondisi Mata Pecaharian, Kaitannya dengan dampak gemapa ini terhadap mata pencaharian masyrakat Kabupaten Lombok Utara adalah, bahwa masyrakat Lombok Utara biasanya menggantungkan hidupnya atau bermata pencaharian di sektor pertanian, jasa serta perhotelan atau pariwisata dan sektor perdagangan, setelah terjadinya gempa khusunya di Kabupaten Lombok Utara banyak mata pencaharian masyrakat yang hilang ataupun menurun, hal ini dikarenakan adanya berbagai kerusakan di berbagai fasilitas ekonomi seperti pasar, supermasrket dan lain sebagainya

Kondisi Pendapatan, Terjadinya gempa yang meluluh lantahkan pulau lombok serta daerah yang terdampak parah adalah Kabupaten Lombok Utara, mengakibatkan pendapatan dari pemerintah daerah setempat banyak mengalami penurunan hal ini diakibtkan banyaknya masyrakat yang kehilangan mata pencaharian, serta banyaknya fasilitas-fasilitas ekonomi yang rusak. Berdasrkan keterangan dari pejabat daerah maka dapat disimpulkan bahwa terjadinya gempa Lombok ini berdampak sangat besar bagi pendapatan daerah tersebut yakni Kabupaten Lombok Utara, hal ini dikarenakan banyaknya masyrakat yang kehilangan mata pencaharian, sehingga berdampat secara agregat ke PAD (Pendapatan Asli Daerh) di Kabupaten Lombok Utara. 
Jurnal Kompetitif : Media Informasi Ekonomi Pembangunan, Manajemen dan Akuntansi

Vol. 6 No. 2, September 2020

\section{KESIMPULAN}

1. Bahwa dampak gempak Lombok ini memberikan dampak yang begitu signifikan bagi kondisi sosial ekonomi masyrakat daerah Kabupaten Lombok Utara

2. Dari kondisi sosial dengan instrumen pengkajian yakni, kondisi demografi, jumlah fasilitas kesehatan, fasilitas pendidikan dan kondisi perumahan, bahwa gempa ini membuat berbagai kerusakan terhadap beberapa fasilitas pendidikan, kesehatan serta perumahan masyrakat daerah Kabupaten Lombok Utara sedangkan kondisi demografi banyak menimbulkan korban jiwa serta masyrakat banyak yang mengungsi di tempat-tempat lain, dan hampir setengah dari jumlah penduduk yang ada di Kabupaten Lombok Utara.

3. Dari segi kondisi ekonomi, dengan instrumen pengkajian adalah matapencaharian serta pendapatan, dari hasil kajian gempa Lombok ini memberikan pengaruh yang signifikan terhadap mata pencaharian masyrakat Kabupaten Lombok Utara. Rata-rata pendapatan masyrakat yang bekerja sebagai pedagang mengalami penurunan sebesar 50\%, yakni semula sebelum gempa pendapatan pedagang di Desa Sokong mencapai 1-1,5 juta perhari, tetapi pasca gempa menyebabkan pendapatan perhari yang mereka dapat sebesar 600 ribu Rupiah, serta menurunnya pendapatan dari pemerintah daerah setempat. Dari hasil kajian dan data bahwa untuk Kabupaten Lombok Utara sebelum gempa banyak dari sektor-sektor jasa (pariwisata) selain dari sektor pertanian, namun APBD dari Kabupaten Lombok Utara masih tergantung dari dana alokasi umum, sedangkan persentase dari PAD nya sebesar $4,79 \%$ dari total APBD murni . sedangkan hasil kajian pasca gempa Lombok banyak masyrakat yang kehilangan mata pencahariannya, terutama di sektor pertanian dan sektor pariwisata, sehingga berdampak bagi penurunan penerimaan asli daerah Kabupaten Lombok Utara dalam hal ini yakni PAD akan secara langsung akan berkurang, karena rata-rata PAD Lombok Utara banyak dari sektor pariwisata

\section{SARAN}

Dari hasil penelitian tersebut bahwa peneliti memberikan saran kepada pemerintah daerah setempat diantaranya: 
1. Pemerintah daerah setempat harus segera memberikan bantuan bagi masyrakat yang kehilangan rumah, serta pemerintah harus segera memperbaiki beberapa fasilitas publik yang rusak seperti, sekolah, rumah sakit, dan tempat-tempat ibadah

2. Pemerintah harus segera memberikan beberapa pelatihan kepada masyrakat mengenai mitigasi bencana guna meminimalir resiko bencana.

3. Pemerintah harus segera memulihkan kembali prekonomian masyrakat daerah Kabupaten Lombok Utara dengan cara membangun kebali sarana ekonomi seperti pasar dan dan sarana-sarana lainnya yang menunjang mata pencaharian masyrakat daerah setempat

4. Pemerintah harus mengadakan peralalatan untuk pendeteksi gempa dan pergerakan tanah guna mitigasi.

\section{DAFTAR PUSTAKA}

Anastasia. 2010."Perubahan Pekerjaan Masyarakat Sebagai Akibat dari Bencana (Studi kasus Kawasan Wisata Vulcano Tour Gunung Merapi, Desa Umbulharjo, Cangkringan, Sleman). elib.unikom.ac.id (diakses pada tanggal 18 oktober 2018

AusAID, (May 2005), Economic Impact of Natural Disasters on Development in The Pacific

Benson, C.,(1997), The economic impact of natural disasters in the Philippines. Working paper 99. London: Overseas Development Institute.

Buckle, P., Marsh, G. and Smale, S., (2001), Assessment of personal and community resilience and vulnerability. Emergency Management Australia Report $15 / 2000$.

Bull, R. (1994): Disaster economics. Disaster Management Training Programmes. Geneva: UNDP and DHA. Drèze,

Gilarso. (1994) . Pengantar Ilmu Ekonomi Makro. Edisi Pertama. IKAPI. Yogyakarta.

Irsyam, dkk, (2012), Perbandingan Spektra Desain Beberapa Kota. Besar Di Indonesia Dalam SNI Gempa. Jurnal diaksel tanggal 18 september 2018

J. and Sen. A., (1989), Hunger and public action. Oxford: Oxford University Press. Hewitt, K.,(1997), Regions at risk. Harlow:

J.Moleong, Steven. (1999) .Metodologi Penelitian Kualitatif. Bandung: Remaja Rosdakarya.

Longman. Noy,Ilan (2007), The Macroeconomic Concequences of Disasters, SCCIE Working Paper 07-15

Mardalis. (1999). Metode Penelitian Suatu Pendekatan Proposal. Jakarta: Bumi. Aksara.

Novenanto Anton. 2017. "Melihat Kasus Lapindo Sebagai Bencana Sosial”. Journal Unair. www.journalUnair.ac.id (diakses pada tanggal 18 oktober 2018) 
Noy, (2007), Foreign Direct Investment and Economic. Online Journal of Instructional Technology, vol 2 no 2, 27-40.

Ohnaka, (2013), The Physics of Rock Failure and Earthquakes. Buku Seismologi, BMKG., Jakarta.

Ramanditya.2014."Integrasi Rehabilitasi Sosio Ekonomi Penduduk Setelah Gunung Merapi Tahun 2010 terhadap Perencanaan Pemulihan. www.rdi.or.id (diakses pada tanggal 18 otoberr 2018)

Soekanto, Soerjono. (1982). Sosiologi Hukum dalam. Masyarakat,Jakarta : CV. Rajawali. Afrizal. 2014

Sri Moertiningsih. (2011). Dasar-Dasar. Demografi Edisi Revisi 2. Jakarta: Selamba Empat.

Soediyono. (1992). Ekonomi Makro Pengantar Analisa Pendapatan. Jurnal JEB Volume 3 no 2 Oktober 2018

Pelling, M., (2002), Assessing urban vulnerability and social adaptation to risk: evidence from Santo Domingo. International Development Planning Review 24(1), 59-76.

United Nations Disaster Relief Coordinator (UNDRCO), (1991), Mitigating natural disaster phenomena, effects and options: a manual for policy makers and planners. New York: UN.

U.S. Geological Survey, Reston, Virginia: 2015. Manuscript approved for publication For more information on the USGS - the Federal source

Wikepedia // Teori Gempa Bumi . Diakses tanggal 15 september 2018

Wikepedia// Earth. Diakses tanggal 15 september 2018

Spence, Sipkins y Choy., 1989, Geographic distribution of the earthquakes included in the catalog of National Seismological

Vermeiren, J.C.,(1991), Natural disasters: linking economics and the environment with a vengeance. In Girvan, N.P. and Simmons, D.A., editors, Caribbean ecology and economics. Barbados: Caribbean Conservation Association

Zapata-Marti, R.,(1997), Methodological approaches: the ECLAC methodology. In Center for the Research on the Epidemiology of Disasters (CRED), Assessment of the economic impact of natural and man-made disasters. Proceedings of the expert consultation on methodologies, Brussels, 29-30 September, Universite Catholique de Louvain, Belgium, 10-12. 